\title{
Peace Education in State Building: Towards a Better Understanding of Post-War Sierra Leone
}

\author{
Brima Patrick Kapuwa \\ Njala University, Freetown, Sierra Leone \\ Email: maheikapus@gmail.com
}

How to cite this paper: Kapuwa, B. P. (2021). Peace Education in State Building: Towards a Better Understanding of Post-War Sierra Leone. Open Journal of Social Sciences, 9, 71-81.

https://doi.org/10.4236/jss.2021.99006

Received: August 9, 2021

Accepted: August 30, 2021

Published: September 2, 2021

Copyright (อ 2021 by author(s) and Scientific Research Publishing Inc. This work is licensed under the Creative Commons Attribution International License (CC BY 4.0).

http://creativecommons.org/licenses/by/4.0/

\begin{abstract}
Peace building in post was countries have posed several challenges to an extent that the former war-torn countries stand the probability of relapsing into conflict if the very reasons for which they went to war were not addressed. Often and again, what characterizes negotiation and mediation skills to end a conflict are most times supply driven from the perspectives of the international community. In very rare circumstances, the parties to the conflict are involved in developing the framework for peace talks, rather the parties are brought to the negotiating table to discuss the framework developed by the peace experts. In this piece, it is argued that ignoring core competencies and skills of peace education and sensitization will continue to pose serious challenges to peace and stability especially if the very reasons for which the parties went to war are not included in an inclusive peace education framework.
\end{abstract}

\section{Keywords}

Peace Education, Peacebuilding, Disarmament, Demobilization, Reintegration

\section{Introduction}

A major challenge of UN peace builders the world over continues to face is the possibility of former war-torn states relapsing into violent conflict barely a decade after their intervention. When parties to a conflict clash, reasons abound as to why they went to war. For most countries, it is the accelerated pace of decadence across the socio-political, economic and cultural spectrum across the country characterized by gross Human Right abuses and violations that give way to war.

In this piece, it is argued that Peace building initiatives especially for third world countries like Sierra Leone would continue to gallop with huge potentials to re- 
lapse into conflict if measures are not taking to address the very excesses of the liberal peace proposition. As argued by Collier, he asserts that an econometric analysis of wars since the 1960s posits that post war countries are at risk of returning to conflict immediately after the conflict with a $40 \%$ probability. Coller (2000) notes that "there is a risk that falls at around one percentage point for each year of peace, and that in the first decade of post-conflict peace, societies face roughly double the risk of conflict that the pre-conflict risk factors would predict. Post-conflict societies are thus at substantial additional risk because of what has happened to them during conflict".

This paper argues that the failure on the part of the mediators to Sierra Leone's conflict resolution to concentrate on Peace Education has huge tendencies of relapsing the country into conflict. A better description of what could be described as peace education status quo or the lack of it stems from some insights from the Truth and Reconciliation Commission Report immediately after the peace talks. Prior to and during the negotiation phase, it was discovered that education for peace was absent during engagements of warring parties and did not form future negotiated talks. Social vices like issues of power, injustices, political intimation, corruption, youth unemployment etc, were characteristic of the pre-war years in Sierra Leone. The school system on their part did not have or curricula for peace education. This seeming negative status-quo for peace, and the education for peace accounted for the disconnection in the entire peacemaking processes that eventually made post conflict state building (Peace building) activities short lived or with questions.

Accordingly, Social science researcher of peace and conflict asserts that in the entire Peace processes, i.e. keeping the Peace, Enforcing the Peace and finally Building the Peace, Peace Education remain a key ingredient, the failure of which undermines whatever peace that may have been built. By Peace Education, Abebe, Abesso and Nyawalo (2006) use the UNESCO explanations to mean "a process involving attitude and skills including listening, reflection, problem solving, cooperation and conflict resolution; and behaviors consistent with harmony with oneself, others and your environment". Peace education has not been given much prominence in the resolution stage where the belligerent parties to the conflict agree to meet and discuss the very reasons for the conflict up to cessation of hostilities when the peace is kept. Having understood the very reason for the conflict during the conflict resolution stages, the parties to the conflict needed to understand and appreciate peace education. When one party to the conflict while discussing the reasons for the conflict, breaks ceasefire agreement of keeping the peace by attacking the other faction, it boils down to the failure of what form of education they may have received during this process. It become worse during Peace Enforcement stage because the lack of adequate education about the kind of peace sought makes enforcement difficult. Processes like Disarmament, Demobilization and Reintegration of ex-combatants, eventually produces bad outcomes in building the peace because of education as the missing link in the entire processes. Education for development as emphasized by the (World Bank, 
2012) stresses "Education is central to development. It empowers people and strengthens nations. It is a powerful 'equalizer', opening doors to all to lift themselves out of poverty."

By way of research methodology, this study will observe the following steps: Firstly, a broad introductory/background on the research topic, explanation of research hypothesis and general questions will be presented about Sierra Leone's peace journey. A quick scan on UN peace making instrumentations together with those of the domestic dynamics and capacities in understanding why the country should be ripe for conflict barely a decade after UN interventions. In particular, this study will examine the various processes that led to final peace accord in both Sierra Leone and Liberia with a view to understanding the shortcomings as far as peace education is concerned.

\section{Conceptualizing Peace Education}

The general background as to where and how Peace Education came from is deeply rooted in religious ideologies and teaching ranging from Buddha, Christianity, Islam, and the Lao Tse or Taoism. Broadly speaking, a better understanding of Peace Education revolves around constructivist attributes such as shared values, attitudes, skills, cultural behaviors and knowledge to live in social cohesion with one's environment and the self. It is important to note that peace education that is process driven offers better meaning when we note its attendant socio-cultural needs. Attempting therefore to define Peace Education poses serious challenges as there are no universally acceptable definitions as such.

A better understanding and definition have been postulated by (Harris, 2002) when he opined in the twentieth century that the growth in horrific forms of violence like genocide, modern warfare, ethnic hatred, racism, sexual abuse, domestic violence, gave rise to the birth of peace education where educators from early child care to adult use their professional skills to warn fellow citizens about imminent dangers and advise them about paths to peace. Harris (2002) therefore postulates five broad arguments that offer a better understanding of Peace Education, namely as one that: explains the roots of violence; Teaches alternatives to violence; Adjusts to cover different forms of violence; Peace is a process that varies according to context; and one where conflict is omnipresent. Peace Education mechanism as asserted by Balanandan (1998) aims to "alter beliefs, attitudes, and behavior i.e. from negative to positive attitudes toward conflict as a basis for preventing violence". As a holistic process, Schmidt and Friedman (1988) note that "Peace Education encompasses the physical, emotional, intellectual and social growth of children within the framework that stems from traditional human values." Schmidt and Friedman (1988) explain Peace Education as a philosophy that teaches love, compassion, trust, fairness, co-operation and reverence for the human family and all life on our beautiful planet.

\section{Theory of Peace Education}

In this paper, a number of peace theories are been proposed. These theories will 
help us understand why and how their relevance renders credible explanations and understanding of Peace and Peace education. Our use of these theories and their attendant assumptions will help in our analysis and arguments as to why they are either useful for this paper's hypothetical arguments, or how they can help proffer alternative understanding of Peace and Peace Education. For the purposes of this article, it will scan through peace theories like the Democratic Peace argument by Bruce Russet, Perpetual Peace by Kant and John Galtung's Positive and Negative Peace.

Russet's, the Democratic Peace Theory, generally argues that democracy promotes peace, and that it is very rare for conflicts to occur among countries with the same liberal tenets. The core arguments of the democratic peace theory as argued by Levy (1998) notes that it is very rare for two countries with the same democratic credentials to go to war with each other especially when you take into consideration a wide range of different historical, economic, and political factors suggests that there is a strong predisposition against the use of military violence between democratic states. This condition (Doyle, 1983) emphasize "does not only challenge the validity of other political systems (i.e., fascism, communism, authoritarianism, totalitarianism), but also the prevailing realist account of international relations, which emphasizes balance-of-power calculations and common strategic interests in order to explain the peace and stability that characterizes relations between liberal democracies". To link the Democratic Peace Theory therefore with Peace Education, and because Russet et al. emphasizes on democratic political institutions that makes it difficult for governments to initiate war without the consent of the electorate; and that the accompanying cultural norms mean democracies will favour a peaceful means of conflict resolution with one another; it is therefore prudent that peace education be central in the liberal political order which places premium on elections and democracy. Democracy (Russett \& Oneal, 2000) argue, has the likelihood of reducing conflict by $33 \%$. These interstate rivalries among democracy dyads hardly come by.

In the Perpetual Peace by Kant (1795), he broadly refers to a state of affairs where peace is permanently established over a certain area (ideally, the whole world). Kant builds his hypothetical argument on five broad assumptions to exist in order for Perpetual Peace to prevail namely "that the Civil Constitution of Every State Should Be Republican; that no Treaty of Peace Shall Be Held Valid in Which There Is Tacitly Reserved Matter for a Future War"; that No Independent States, Large or Small, Shall Come under the Dominion of Another State by Inheritance, Exchange, Purchase, or Donation; "that Standing Armies (miles perpetuus) Shall in Time Be Totally Abolished"; and that "No State Shall by Force Interfere with the Constitution or Government of Another State."

Kant's Perpetual Peace like the Democratic Peace, argues that because of what Russett (1993) calls rationality (the costs and risks of war) which directly affects a large segment of the population, the global spread of democracy will result in greater international peace if this occurs in parallel with the strengthening of economic interdependence and international organizations. Doyle (1986) sum- 
marizes that the difficulty lies in the significant risk of instability inherent in the process of democratization and the uncertainty that remains "incomplete in a Kantian world" where the Hobbesian state of anarchy has not yet entirely disappeared from the international system. Peace Education is therefore a useful instrument in enhancing Perpetual peace especially the call for a Republican nature of the constitution, that no state shall come under the other, and that standing armies be abolished. This can properly sit in the Peace Education framework we design for ever nation be they war turn or not.

By positive peace, Galtung rather focuses on those prerequisites and conditions that should exist for sustainable peace to exist such as upholding fundamental freedoms and human rights. Galtung's Negative Peace as defined by Wiberg (2000), notes it to mean the "the absence of organized, personal violence, which is approximately the same as non-war" and positive peace as "requiring the absence of structural violence". The question that comes to mind is an understanding of the link and usefulness of Peace Education in a "Galtungian" World. In positive Peace, the usefulness of Peace education cannot be over emphasized as Civic education activities around issues of Human Rights Education, curricula for schools, should form the basis of Peace education. Human Rights activities around violations, protections should be anchored on a robust peace education model.

Peace Education, Political Stability and Economic Development in Sierra Leone.

During the resolution phase of the conflict in Sierra Leone, what then became the typical approach to the peacemaking process focused on awareness raising and training of combatants to resolve their inter-personal disputes through acceptable negotiation and mediation, such as managing their anger, expectations, improving communications, identifying their needs linked to the reasons for the armed conflict, and managing their emotions etc. formed. In Sierra Leone and like any conflict state, economic activities unquestionably slow down during armed conflict. This is because all efforts are galvanized to prosecuting the war to its conclusion especially as both warring factions design strategies to overcome the other. During this phase, messages for peace are rare and often times, the lack of these messages for peace or respect for combat laws like securing prisoners of war instead of killing them, contribute to a deteriorating state of affairs.

Political stability in Sierra Leone during and after the conflict could be linked to what strategies were designed and linked to the resolution, prevention of conflict and the entire peacemaking, keeping and enforcing processes for the promotion and maintenance of peace. The major cause of the Sierra Leonean conflict that occurred between 1991-2002 were attributed to the failure of democracy and political systems then which restricted democratic practices to one party rule, political intimidation and violence, injustices, institutionalized corruption and human right abuses. In such an environment therefore, it is unquestionable that peace and national cohesion cannot hold and that any form of education for 
peace may just be seen as a waste of time. For Sierra Leone to overcome them, state and non-state actors like civil society groups, religious entities, educational institutions, warring parties, polities parties etc were regularly engaged on the need to preach and promote peace through values such as democracy, respect for human rights, addressing injustices and corruption; and empowering the people so that they can contribute and influence public policy, uphold and protect their rights, participate in electing their leaders and also have the liberty of holding them accountable. Creating this environment was key in firstly bringing the warring factions to the negotiating table, allowing Sierra Leoneans to participate in the election of a government of their choice through multi-party democracy that was suppressed for over three decades, strengthening such democracy through peace education advocacy, an improved justice system and rule of law, and preventing further conflict. The enabling political environment created as a result of educating for peace paved the way for socio-cultural and domestic stability on social issues that had an impact on the maintenance of peace in Sierra Leone. When national cohesion and stability returned to a war-torn society through peace education, issues of corruption and governance shortcomings will be addressed.

Another area that is worth noting is the role of non-state actors like inter-faith groups, civil society groups and their contribution to social stability through peace education. In Sierra Leone the role of religious groups during the peace process was very outstanding. Inter-religious groups comprising of Christian and Islamic leaders mobilized themselves into a formidable force that engaged the warring parties and international partners into drafting a pathway to peace. The Church and Mosque throughout the country played a significant role their messages of peace and respect for human life and rights, the rule of law and democratic principles and values through civic education. This was particularly very successful because in Sierra Leone there are only two forms of religion and that both factions to the conflict (RUF and Government forces).

\section{Peace Education during Conflict Process in Sierra Leone}

Like it has been argued in previous chapters, the nature of education used during the peace-making process in Sierra Leone between 1998-2002 to accounts for the many challenges we see facing the country. Issues around negotiation skills, messaging, addressing the root causes of the conflict did not make their way through the entire process. In the area of negotiation among the warring factions, a key reason why cooperation among the warring factions may not have been smooth was as a result of level of tolerance, kindness and love displayed among and between both the parties to the conflict and mediators. During the resolution phase of the conflict in Sierra Leone, what was lacking was a typical approach to the peace-making process focused on awareness raising and training of combatants to resolve their inter-personal disputes through acceptable negotiation and mediation, such as managing their anger, expectations, improving communications, identifying their needs linked to the reasons for the armed conflict, and manag- 
ing their emotions.

Additionally, communication has a big role to play in conflict resolution and management processes especially when the lack of it often results misunderstanding. In Sierra Leone, both the Revolutionary United Front (RUF) rebel movement and the pro-Government Civil Defense Forces (CDF) were said to be generally illiterates. The only form of messaging they had was to shoot and kill. Observing international standards like taking prisoners of war, spearing civilians (women and children) were never part of their rules of engagement. The Regional mediating group ECOWAS, and UN to the Peace process had to design simple sensible and relevant words messages on the radio for all warring parties to understand. The grand strategy used by peace keepers and civil society organizations was anchored on very concise, straight forward messages detailing what is expected from them. UN and ECOMOG Peace Keepers were very cautious to not solely depend on verbal communications but to also engage them bilaterally in their comfort zone done on the same platform so that all the parties get the same picture.

When it came to the issue of Disarmament, Demobilization and Reintegration of ex-combatants, messages of peace were not directly tailored for sustainable purposes to the combatants. Peace enforcers were only interested in the physical collection of weapons from the combatants without any sustained rehabilitation process through education. Peace mediators needed to pay a particular attention to the reintegration aspect of the peace process. By reintegration, both the RUF, $\mathrm{CDF}$ and Government soldiers were to acquire civilian status and gain sustainable employment and income, thereby dropping the gun. Because serious education did not go into this area through a sustainable program, those war-like conditions started to surface at particular times of the country's history like during elections. This poor nature today accounts for the many instances of violence for survival among youths who were hitherto ex-combatants. A DDR or reintegration package needed to be anchored on an education or sensitization model that required an integrated, holistic approach which places emphasis upon creating a positive relationship between ex-combatants and the communities in which they settle.

\section{State Actors, and Peace Education during Conflict and Conflict Resolution in Sierra Leone}

During the peace process in Sierra Leone, a number of state and non-state actors were somehow visible in the conflict resolution processes. These groups include women, religious groups, Civil Society Organizations etc. Women in Sierra Leone are on record as among the early groups that met with the rebels in their stronghold with a view to encourage them to sit to a negotiating table with the Government of President Kabbah. The Bintumani Conference I \& II that was held in Freetown in 1995 that set the stage for elections and a return to civilian government was pioneered by women, although they were excluded at the Lomé Peace Accord in Abidjan. 
The Civil Society involvement in the peace process was key as they created an enabling environment that enhanced the peace talk, although like the women, they had very little influence on the content and agreement reached. During negotiations, the UN mission that was called UNOMSIL designed a support mechanism for the RUF and AFRC in wat they tagged as "Family meeting" to prepare them for the Lomé negotiations. It would have made much sense had the CSOs been involved in such "family meeting" and if peace education was factored in it. Another opportunity to have explored was in 1999 when the National Commission for Democracy and Human Rights held a three-day consultative conference of Members of Parliament, Paramount Chiefs, Political Parties and other CSOs who met to endorsed President Kabbah Government and the Abidjan and Conakry Agreement as the basis for negotiated settlement. Again, the three-day engagement failed to include any sustainable framework for Peace Education among these state and non-state actors.

The Inter-religious council was another great entity that had a unique role in the entire peace process. They were instrumental in initiating dialogue with the RUF and also met with the CDF and helped to facilitate the Lomé peace talks. What was not clear was the nature of peace messages that were echoed in those engagements. Naturally, one would expect that because Sierra Leone has only two religions (Islam and Christianity), these religious leaders were expected to institute peace education messages that would not only target an end to the war, but one that is sustainable and useful even after peace may have been attained.

\section{The Way Forward for Post War Challenges and Peace Education in Sierra Leone}

While the actors to the peace process were sincere about ending the decade old conflict in Sierra Leone, what came out clear in both their approaches and tools for resolution was a "supply driven" approach to resolving the conflict and peace building. Unquestionably, no two conflict situations are the same therefore to use a uniform approach to resolving a conflict could have far reaching implications.

Another challenge that the failure of a sustained peace education would bring is curbing corruption and promotion the vice of injustice in Sierra Leone. A peace education framework that is all inclusive should agitate for budgetary allocations that targets sensitizations and awareness raising on corruption, political intimidation, the rule of the law without fear or favour, and an informed populace on transparency and accountability. Post war state institutions are required to focus on addressing these governance deficiencies so as to ensure that the very reason(s) for which Sierra Leone went to conflict are addressed.

Addressing issues of unemployment and giving the youth hope for a better future needs urgent attention. Since these youths formed the majority of combatants during the war, Peace mediation brokers failed to address their impoverished nature. Rather attention was paid to an immediate end to the conflict with a mad rush for disarmament, and a hurriedly conducted election. Designing a 
peace education framework that involves economic development, skills training, education, and the restoration of basic services was going to make much sense if it was fully implemented. The international peace brokers and donors rather concentrated on disarmament and reintegration as a strategy for preventing future violence among youth without addressing strategies for macroeconomic growth and spending caps as key factors that undermined economic and educational opportunities for those same youth.

It is our view that it's never late to inculcate peace education in Sierra Leone's post conflict recovery strategy. Excuses around donor requirements for budget allocation and execution like "privatization in public enterprises, should not be countenanced that much because of foreign aid. There should be a robust peace education around opportunities in agriculture that is geared towards removing trade obstacles, and should as (Collier, 2000) notes focus on growth that typically peaks in the second four-year period after conflict, and this period is typically where external funding reduces.

Post war cohesion and stability in Sierra Leone as echoed by Davies (2004) should be anchored on four relevant questions: "What is the trajectory of change is the Peace Education package offering? Secondly, who plans and decides what. Should it be demand driven of supply driven? Thirdly, what is to be reconstructed and how does Peace Education contribute to it? Finally, who monitors and how is progress evaluated?"

\section{Conclusion}

Several scholars have posited that war/conflicts undermine national cohesion and stability. When therefore efforts are galvanized to end such given war, practical approaches like peace education should be mainstreamed. The practice of Peace education is a political exercise, economic, moral or ethical, has proven to be a major means through which the rhetoric of conflicts or the probability of returning to war can be drastically reduced. While we note that conflict is inevitable, we also contend that violence is not; therefore, parties to a conflict need to be taught alternatives to resolving conflicts, thereby letting them know that violence is never an alternative means to achieve their goals. Peace Education is a means to this end as it educates warring parties on their responsibilities, and also cautions peace makers to take onboard those very issues that may have caused the war.

In Sierra Leone's post conflict state building therefore and given that efforts to end the war were not wholistic to capture and inculcate core peace education activities in the negotiation, disarmament, demobilization and reintegration phases, this paper concludes that all is not yet lost for Sierra Leone's post war stability. There has been relative stability as structural violence has not surfaced since the war ended almost two decades ago in 2002. The country is not currently suffering from dictatorship or a prolonged one-party system as over 4 general elections have been conducted since the overthrow of one-party system in favour of 
multi-party system.

There are a number of obstacles which the post DDR offered to national stability even up to date. Like (Colletia et al., 1996) argued, "demobilization and reintegration of ex-fighters are the key to effective transition from war to peace". The challenge that this poses even to today's national cohesion and stability is that after disarming and demobilizing over 46,000 ex-combatants who were mostly children and youths, these combatants were to be transitioned into apprenticeships of various kinds alongside with an entitlement package which provided safety net during the transition period. After their trainings, most these youths could not find jobs and render them jobless. It accounts for the major problem of unemployment facing the country. The same can be said about social justice, corruption etc. which still faces serious challenges for the post conflict stability of Sierra Leone.

A national framework of detailed programming is therefore required to make very conscious effort at peace education in schools, Community activities, public and private sector works, the ordinary citizenry, and stat/non-state actors.

\section{Conflicts of Interest}

The author declares no conflicts of interest regarding the publication of this paper.

\section{References}

Abebe, T. T., Abesso, A., \& Nyawalo, P. A. (2006). Peace Education in Africa. Addis Ababa University of Press.

Balanandan, E. (1998). Social Development, Including Questions Relating to the World Social Situation and to Youth, Ageing, Disabled Persons and the Family. Report of the 3rd Committee: General Assembly, 54th Session.

Coller, P. (2000). Economic Causes of Civil Conflict and their Implications for Policy. World Bank.

Davies, L. (2004). Education and Conflict: Complexity and Chaos. Routledge Falmer.

Doyle, M. W. (1983). Kant, Liberal Legacies, and Foreign Affairs, Part 1. Philosophy \& Public Affairs, 12, 213-215.

Doyle, M. W. (1986) Liberalism and World Politics. The American Political Science Review, 80, 1156-1157. https://doi.org/10.1017/S0003055400185041

Harris, I. M. (2002). Peace Education Theory. Department of Educational Policy and Community Studies, University of Wisconsin-Milwaukee.

Kant, I. (1795). Perpetual Peace: A Philosophical Sketch. Essays on Kant's Cosmopolitan Ideal.

Levy, J. S. (1988). Domestic Politics and War. The Journal of Interdisciplinary History, 18, 661-662. https://doi.org/10.2307/204819

Colletia, N. J., Kostner, M., \& Wiederhofer, I. (1996). The Transition from War to Peace in Sub-Saharan Africa. The World Bank. https://doi.org/10.1596/0-8213-3581-2

Russett, B. M. (1993). Democracy, War and Expansion through Historical Lenses. European Journal of International Relations, 15, 9-36.

https://doi.org/10.1515/9781400821020 
Russett, B., \& Oneal, J. R. (2000). Triangulating Peace: Democracy, Interdependence, and International Organizations (394 p). W. W. Norton \& Company.

Schmidt, F., \& Friedman, A. (1998). Peacemaking Skills for Little Kids. Grace Contrino Abrams Peace Education Foundation.

Wiberg, H. (2000). Peace Research: Present Past and Future. Journal of Peace Research, 71.

World Bank (2012). Education and Development. World Bank. http://web.worldbank.org 